\title{
A Review of the Various Roles and Participation Levels of B-Cells in Non-Infectious Uveitis
}

\author{
Lei Zhu ${ }^{\dagger}$, Binyao $\mathrm{Chen}^{\dagger}$ and Wenru Su* \\ State Key Laboratory of Ophthalmology, Zhongshan Ophthalmic Center, Sun Yat-sen University, Guangzhou, China
}

\section{OPEN ACCESS}

Edited by: Attila Mócsai,

Semme/weis University, Hungary

Reviewed by:

Saba Nayar

University of Birmingham,

United Kingdom

Cheng Yu,

National Eye Institute (NEI),

United States

*Correspondence:

Wenru Su

suwr3@mail.sysu.edu.cn

${ }^{t}$ These authors have contributed equally to this work and

share first authorship

Specialty section: This article was submitted to Autoimmune and

Autoinflammatory Disorders, a section of the journal

Frontiers in Immunology

Received: 04 March 2021 Accepted: 28 April 2021

Published: 14 May 2021

Citation:

Zhu L, Chen B and Su W (2021) A

Review of the Various Roles and

Participation Levels of B-Cells

in Non-Infectious Uveitis.

Front. Immunol. 12:676046.

doi: 10.3389/fimmu.2021.676046
Non-infectious uveitis is an inflammatory disorder of the eye that accounts for severe visual loss without evident infectious agents. While $T$ cells are supposed to dominate the induction of inflammation in non-infectious uveitis, the role of $B$ cells in the pathogenesis of this disease is obscure. Therefore, this review aimed to discuss diverse B-cell participation in different non-infectious uveitides and their roles in the pathogenesis of this disease as well as the mechanism of action of rituximab. Increasing evidence from experimental models and human non-infectious uveitis has suggested the participation of B cells in noninfectious uveitis. The participation levels vary in different uveitides. Furthermore, B cells play multiple roles in the pathogenic mechanisms. B cells produce autoantibodies, regulate $T$ cell responses via antibody-independent functions, and constitute ectopic lymphoid structures. Regulatory B cells perform pivotal anti-inflammatory functions in noninfectious uveitis. Rituximab may work by depleting pro-inflammatory B cells and restoring the quantity and function of regulatory B cells in this disease. Identifying the levels of B-cell participation and the associated roles is beneficial for optimizing therapy. Diversified experimental model choices and emerging tools and/or methods are conducive for future studies on this topic.

Keywords: uveitis, B cell, autoimmune, B-cell depletion, Rituximab

\section{INTRODUCTION}

Uveitis is an inflammatory disorder of the eye (1). Although it has a relatively low prevalence, it is a major cause of severe visual impairment accounting for $10-20 \%$ of visual loss worldwide, and up to $35 \%$ of patients with uveitis suffer from effects ranging from severe visual loss to legal blindness (2, 3). It is classified into either infectious or non-infectious uveitis. Non-infectious uveitis is believed to be autoimmune or immune-mediated (4) and is the more prevalent subtype in developed countries (5). Corticosteroids have always been the cornerstone of non-infectious uveitis treatment, albeit with serious side effects due to long-term and high-dose use (6). Immunosuppressants lack universal efficacy and need to be combined with systemic steroids to maintain disease control (7). Biologics are promising therapies that help overcome these handicaps, but a deeper understanding of the pathogenic components involved in non-infectious uveitis is required for improving the precision of targeting.

Non-infectious uveitis is mainly regarded as a T cell-induced disease, and the role of B cells in the pathogenesis of this disease is not yet fully understood (8). Rituximab is a type of B-cell depletion 
therapy that also includes the humanized B cell-activating factor (BAFF)-targeting monoclonal antibody, Belimumab (9), or the humanized anti-CD22 antibody, Epratuzumab (10). Rituximab treatment has been shown to be useful for treating several human non-infectious uveitides $(11,12)$ which indicates the participation of B cells in this inflammatory disease; however, this does not conclusively elucidate the role of $\mathrm{B}$ cells in the disease. Additionally, the different participation levels of B cells in the disease has not been extensively studied. Therefore, in this review, we explored the different participation levels of B cells and their roles in the pathogenesis of this inflammatory disease. The possible mode of action of rituximab in non-infectious uveitis is also discussed. Identifying the participation of B cells in non-infectious uveitis will help to advance the development or clinical use of medicines targeting B cell or B cell-associated molecules to improve the prognosis of patients.

\section{NON-INFECTIOUS UVEITIS}

\section{Definition and Classification}

Uveitis is an inflammatory disorder of the eye and involves the vascular uveal tract, retina, optic nerve, and vitreous $(1,13)$. Etiologically, uveitis is simply classified as infectious uveitis if obvious infectious agents are present, or as non-infectious uveitis if it is suspected to be autoimmune or immune mediated (4). Occasionally, infections may be a potential cause of noninfectious uveitis (14). Non-infectious uveitis is the major focus of this review. Clinically, uveitis is classified anatomically as anterior uveitis (involving the iritis, ciliary body), intermediate uveitis (involving the pars plana, vitreous, and peripheral retina), posterior uveitis (involving the retina and choroid), and panuveitis (involving all ocular tissue) (15). Uveitis can be confined to the eye or be a part of systemic diseases with complex symptoms and varied etiology (16). In approximately $50 \%$ of patients with uveitis, a systemic disease will be identified (17) and in the remaining patients, idiopathic uveitis is diagnosed. Common causes of noninfectious uveitis include human leukocyte antigen (HLA)-B27 associated anterior uveitis, Vogt-Koyanagi-Harada syndrome (VKH), sympathetic ophthalmia, Behçet disease, sarcoidosis, Fuchs uveitis syndrome, and multifocal choroiditis (14). Juvenile idiopathic arthritis-associated uveitis (JIAU) is the most common non-infectious uveitis in children in the developed world (18). Therefore, the following content associated with human noninfectious uveitis will be focused on the uveitides discussed above.

\section{Therapy}

Corticosteroids are the mainstay of therapy for non-infectious uveitis. In patients with acute and anterior uveitis, topical corticosteroids and cycloplegic and/or mydriatic agents may help to achieve good results. Unfortunately, patients with chronic, intermediate, posterior uveitis, or panuveitis require more aggressive therapy. Systemic steroids are initially administered, followed by immunosuppressants such as methotrexate and mycophenolate if further anti-inflammatory intervention is required $(17,19)$. Corticosteroids and conventional immunosuppressants frequently cause side effects in patients (7).
Fortunately, biologics may be a remedial choice for patients with refractory non-infectious uveitis. Anti-tumor necrosis factor (TNF) therapy was determined to be useful for controlling several recalcitrant uveitides $(20,21)$; IL-6 inhibitors also showed efficacy in refractory JIA-associated uveitis, Behcet's uveitis and so on $(22,23)$. Significantly, a growing number of reports have supported the use of rituximab, a type of B-cell depletion therapy, for refractory noninfectious uveitis $(11,12)$; this supports the hypothesis that B cells contribute to the pathogenesis of non-infectious uveitis. Deeper insights into major pro-inflammatory and anti-inflammatory components involved in the pathogenesis of non-infectious uveitis are conducive for optimizing biologic therapy in this disease.

\section{Experimental Models for Non-Infectious Uveitis}

Experimental autoimmune uveitis (EAU) is the most widely studied disease model for human non-infectious uveitis (24). In EAU, immune responses targeting the neural retina and related tissue are mainly induced by $\mathrm{T}$ cells $(25,26)$. Both active immunization of retinal antigens and adoptive transfer of autoreactive T cells can induce EAU in genetically susceptible animals (27). In addition, spontaneous EAU can be established by gene engineering in animals (16). The most well-known retinal autoantigens are interphotoreceptor retinoid-binding protein (IRBP) and soluble antigen (S-Ag) (25). EAU can be established in a variety of animals such as primates, rats, and mice, among others. Of these, mice and rats are the most widely used animals (28). Experimental models recapitulating different uveitides are pivotal for exploring the pathogenic mechanisms of the disease (26). However, no single animal model represents the complete spectrum of human non-infectious uveitis (26). Some discrepancies inevitably exist between EAU and human noninfectious uveitis. For example, T cells tend to target a single retinal antigen in EAU whereas human non-infectious uveitis is likely induced by various $\mathrm{T}$ cell populations (29). For the most widely used experimental animal, the development, phenotypes, and immunoglobulins produced by $B$ cells of mice are significantly different from B cells of humans (7). The choroid is much thicker in the eyes of humans than in mice. A thicker choroid might contribute to the development of ectopic lymphoid-like structures (ELSs) which are conducive for antibody production (29). These findings indicate the limitation in EAU to fully represent human non-infectious uveitis. Indeed, no adequate animal model can currently represent the pathogenic mechanisms of JIAU (30).

\section{Pathogenic Mechanisms Derived From Studies on the EAU Model}

Studies on EAU demonstrated that non-infectious uveitis is a $\mathrm{T}$ helper (Th)1/Th17 cell-driven disease (8). Activated retinal antigen-specific Th1 or Th17 cells can pass the blood-retinabarrier, break it and secrete cytokines and chemokines to attract inflammatory cells including granulocytes, macrophages/ monocytes, and non-specific lymphocytes into eyes to develop inflammation and destroy the ocular tissue $(16,28)$ (Figure 1). Both Th1 and Th17 cells can independently transfer the disease 


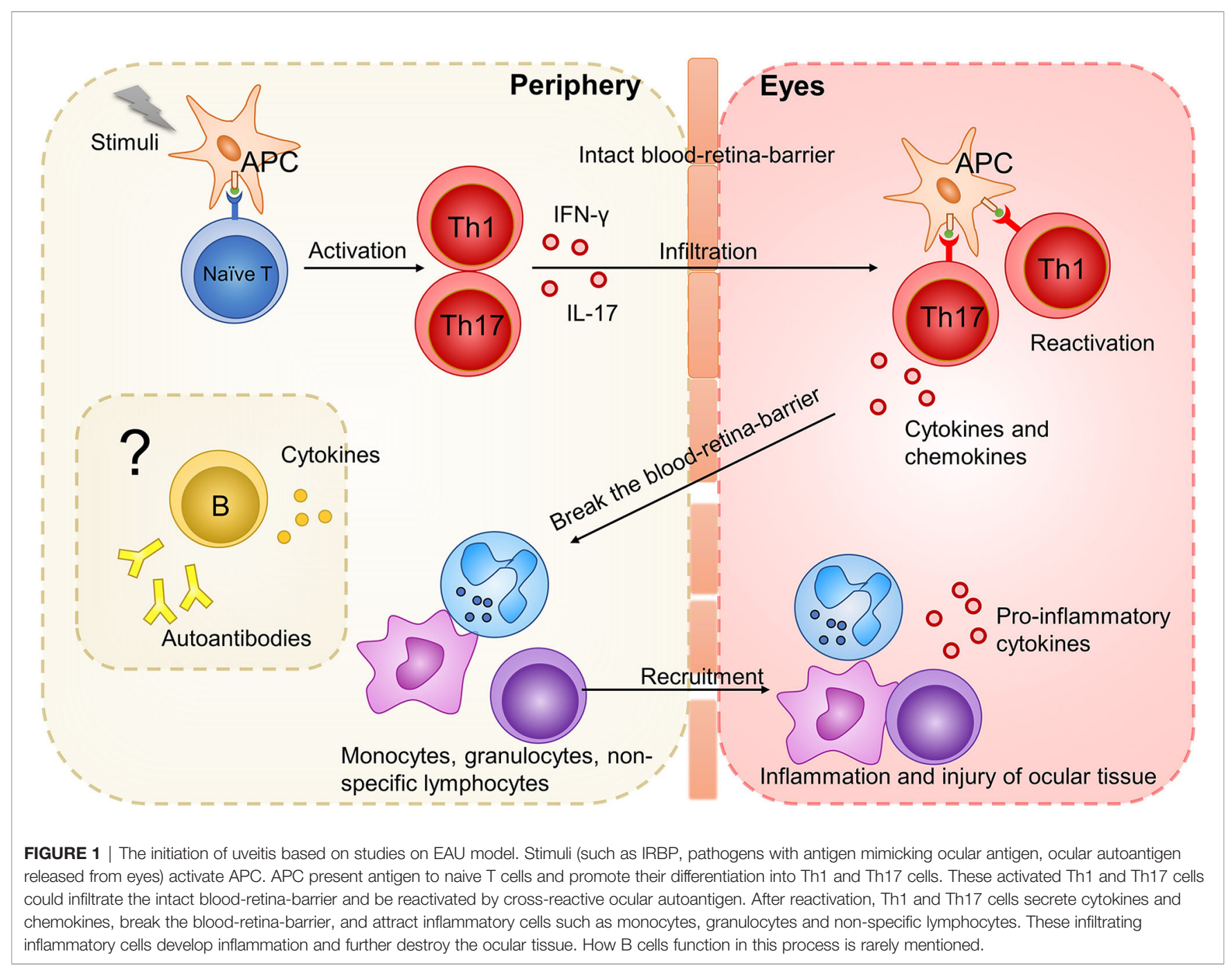

to naïve mice, and the type that dominates the disease depends on the model and the method from which the disease is induced $(16,31)$. Regarding cytokines, interferon (IFN) $-\gamma$ and interleukin (IL)-17 dominate Th1- and Th17-mediated inflammation, respectively. Increased concentrations of TNF- $\alpha$ in tissue drive $\mathrm{T}$ cell responses and macrophage activation in non-infectious uveitis (32). In contrast, IL-10 and transforming growth factor (TGF)- $\beta$ are pivotal anti-inflammatory cytokines mainly secreted by regulatory $\mathrm{T}$ cells (Tregs) in non-infectious uveitis (33). For B cells which play a significant role in autoimmunity, their participation in the pathogenesis of uveitis is rarely mentioned.

However, some studies show results contradicting the pathogenic mechanisms derived from EAU. For example, IFN- $\gamma$ knockout mice developed even more severe uveitis than did wildtype mice (34). Phase III dose-dependent studies for secukinumab (human antibody targeting against IL-17A) in uveitis failed to show significantly better efficacy than the placebo (35). This discrepancy might be attributed to the differences between EAU and human non-infectious uveitis as we discussed above, and the differences among various experimental models. According to a review published by Caspi et al, many experimental models with varied features have been established (16). Therefore, the current pathogenic mechanisms derived from EAU might be incomplete to apply to all experimental models and human non-infectious uveitis. It is tempting to assume that other factors may be involved in the pathogenesis of non-infectious uveitis in specific experimental models and patients. We can speculate that these factors are B cells because evident B cell infiltration was found in both experimental models and humans with non-infectious uveitis (36-38).

\section{PARTICIPATION OF B CELLS IN NON-INFECTIOUS UVEITIS}

In humans, B cells develop from hematopoietic stem cells in the bone marrow. After an intricate developmental process, B cells ultimately develop into plasma cells that secrete antibodies or memory B cells (39). B cells are pivotal components of both humoral immunity and autoimmunity because of their exclusive ability to produce antibodies (40). Other antibody-independent capacities have also received a lot of attention. The pathogenic 
mechanisms derived from EAU might be incomplete to apply to all experimental models and humans with uveitides as alluded earlier. It is rational to speculate that the involvement of B cells in non-infectious uveitis might be the missing part of the pathogenic mechanisms derived from EAU. Increasing evidence from experimental models and human non-infectious uveitis also supports the involvement of B cells in noninfectious uveitis.

\section{B-Cell Participation Varied With Different Uveitides}

Non-infectious uveitis is a group of heterogeneous diseases with diverse etiologies. Differences exist between EAU and humans non-infectious uveitis, and the pathogenic mechanisms may also be different, as discussed above. Seemingly, differences also exist in multiple clinical subtypes of human non-infectious uveitis. Cytokine and chemokine profiles were found to be different between human non-infectious uveitis subtypes $(41,42)$. Lymphocyte population (CD4+ and CD8+ T cells and CD19+ $\mathrm{B}$ cells) infiltrating the vitreous also varied with uveitis etiologies (43). Therefore, B-cell participation may not only differ between EAU and human non-infectious uveitis, but also varies with distinct human non-infectious uveitides. Accordingly, we provide evidence of B-cell participation in animal models and several common human non-infectious uveitides to explore diverse B-cell participation in EAU and various human noninfectious uveitides (Table 1).

\section{B-Cell Participation in EAU}

The number of B cells infiltrating the ocular tissue during uveitis is different depending on the experimental model used. The cell population in the eye also changes over time: while neutrophils dominate the acute stage of retinal inflammation, lymphocytes dominate the chronic stage (72). In most uveitis-induced rats or mice, a small number of $B$ cells and plasma cells were reported to infiltrate in inflammation (a report showed a concrete ratio of 1:4 between CD19+ B and CD4+ T cells), and an increase in the number of $\mathrm{B}$ cells is associated with extended disease duration and aggravated severity (44-46). These data suggest that B cells participate in the pathogenesis of EAU, but only play a minor role in most cases. Chronic inflammation may lead to B cell infiltration. The increased B cell number may lead to persistent disease owing to antibodies produced by plasma cells or other pro-inflammatory functions of B cells. However, in another primate model, a ratio of 1.4:1 between infiltrating $\mathrm{CD} 3+\mathrm{T}$ and CD19/CD22+ B cells has been found during inflammation (38). The proportion of infiltrating B cells is much higher than that in rats or mice, suggesting that B cells may participate in human non-infectious uveitis more actively than we previously considered, because primates are more semblable to humans. Regarding autoantibodies, which are exclusively secreted by B cells, although transfer of immune serum alone fails to transfer uveitis to recipients, transfer of $\mathrm{T}$ cells with immune serum is associated with a higher disease severity compared to the transfer of $\mathrm{T}$ cells alone. This suggests that circulating antibodies may be

TABLE 1 | Evidence of B-cell participation in different uveitides.

\begin{tabular}{|c|c|c|}
\hline Different uveitides & Evidence & Reference \\
\hline \multirow[t]{2}{*}{$\begin{array}{l}\text { EAU induced in rats or } \\
\text { mice }\end{array}$} & $\begin{array}{l}\text { a. Number of B cells that infiltrated into the eyes was lower than that of T cells. Increased B cell numbers correlated } \\
\text { with extended disease duration and severity }\end{array}$ & $(44-46)$ \\
\hline & b. Transferring $T$ cells with immune serum exacerbated EAU more than did transferring $T$ cells alone & (25) \\
\hline $\begin{array}{l}\text { EAU induced in } \\
\text { primates }\end{array}$ & a. The number of infiltrating B cells and T cells in ocular tissue was similar & (38) \\
\hline Juvenile idiopathic & a. Plasma cells predominantly constituted the infiltrates with focal aggregates of CD20 positive cells. & $(36,47-50)$ \\
\hline \multirow[t]{4}{*}{ arthritis } & b. Elevated immunoglobulin in the vitreous fluid and anterior chamber exudate & $(36,51)$ \\
\hline & c. Upregulated B cell-specific genes and proteins in the iris tissue & $(30)$ \\
\hline & d. Anti-ocular serum antibodies were more frequently detected & $(52)$ \\
\hline & e. A patient automatically recovered from uveitis after developing common variable immunodeficiency & (53) \\
\hline $\begin{array}{l}\text { Sympathetic } \\
\text { ophthalmia }\end{array}$ & $\begin{array}{l}\text { a. In most cases, T cells were dominantly infiltrated into the eyes. B cells outnumbered T cells in four out of } 29 \text { eyes and } \\
\text { all nine eyes in two independent reports. The predominant B cells correlated with longer disease duration }\end{array}$ & $(37,54,55)$ \\
\hline \multirow[t]{2}{*}{ Behçet disease } & a. Small number of B cells, plasma cells, and antibodies in the aqueous humor and ocular tissue & $(56,57)$ \\
\hline & $\begin{array}{l}\text { b. Modified B-cell function in the serum: increased activated, memory, and spontaneous lg-secreting B cells; } \\
\text { upregulated B cell function indicated by the gene expression of peripheral blood cells; elevated serum immunoglobin } \\
\text { levels }\end{array}$ & $(58-61)$ \\
\hline Vogt-Koyanagi-Harada & a. The number of B cells in the ocular tissue is similar to that in Behçet disease & $(62,63)$ \\
\hline syndrome (VKH) & b. Antibodies against ocular structures in the serum & $(64)$ \\
\hline Sarcoidosis & a. The number of B cells in the ocular tissue is similar to that in Behçet disease & (65) \\
\hline Idiopathic uveitis & a. The number of B cells in ocular tissue is similar to that in Behçet disease & (66) \\
\hline Multifocal choroiditis & a. Infiltrating B cells outnumbered T cells in inflammatory sites & $(67,68)$ \\
\hline Fuchs' heterochromic & a. Oligoclonal lgG bands were found in the aqueous humor but not in the serum & (69) \\
\hline
\end{tabular}

cyclitis

a. The number of B cells in the aqueous humor collected from patients with idiopathic uveitis is less than that from patients with systemic diseases

b. Levels of B cell-associated molecules (BAFF, APRIL, CXCL13) were significantly higher in the aqueous humor of patients with active uveitis than in healthy controls. APRIL and CXCL13 levels were higher in patients with granulomatous uveitis than in patients with non-granulomatous uveitis.

a-e: the sequence of evidence in each uveitis. 
too large to penetrate the blood-eye barrier (73) and they can gain access and exacerbate EAU after this barrier is disrupted by $\mathrm{T}$ cells (25). It also verified the pro-inflammatory function of autoantibodies against ocular tissue during non-infectious uveitis.

\section{B-Cell Involvement in Several Common Human Uveitides}

In juvenile idiopathic arthritis (JIA), uveitis is the most common extra-articular manifestation. The morbidity of uveitis in children with JIA is approximately $10 \%$, among which non-granulomatous anterior uveitis is the most common form $(74,75)$. Unlike that observed in EAU, a primary B cell infiltrating process was observed in the ocular tissue of patients with juvenile idiopathic arthritis-associated uveitis (JIAU) using immunohistochemical studies. Plasma cells predominantly constitute the inflammation in the iris and ciliary body with a few $\mathrm{T}$ cells and macrophages (47-50). Within these plasma cells, one study showed IgM+ plasma cells were the dominant while the other showed the infiltrate is primarily made up of IgG+ plasma cells $(48,50)$. Focal aggregates of CD20-positive cells have also been shown (36). Correspondingly, elevated amounts of immunoglobulin (Ig) were observed in the vitreous fluid (51) as well as in the anterior chamber exudate, suggesting local production of antibodies (36). Intraocularly upregulated B cell-specific genes and proteins, especially several Ig components in iris tissue, ulteriorly evidence that B cells participate in the pathogenesis of JIAU (30). Regarding serum antibodies, using indirect immunohistochemistry, antiocular serum antibodies can be detected more frequently in JIAU groups than in control groups and predominantly bind to the iris and ciliary body, consistent with the major inflammatory sites (52). Finally, a previous case report showed that a patient automatically recovered from JIAU after developing common variable immunodeficiency, in which defective antibody formation is the most common feature with B cell differentiation failure (53). Overall, JIAU appears to be a B cell (especially plasma cell)-mediated disease. Antibodies produced both in the eye and in the bloodstream exert pathogenic effects.

Sympathetic ophthalmia (SO) is defined as bilateral granulomatous panuveitis following penetrating ocular injury to one eye (76). The results of immunohistochemical studies of choroidal infiltrates of the SO are diverse. In most cases, the choroid is infiltrated mainly by $\mathrm{T}$ cells with a small number of $\mathrm{B}$ cells and plasma cells (54). However, a study that was conducted using 29 cases showed the predominance of CD45RO+ T cells in choroidal infiltrate in 20 cases and that of CD20+ B cells in four cases; it showed equal numbers of $\mathrm{T}$ cells and $\mathrm{B}$ cells in the remaining five cases (37). In another study, CD20+ B cells and CD68+ macrophages were more abundant than CD3+ T cells in all nine cases (55). The predominance of $\mathrm{B}$ cells correlated with a longer duration of the disease (37); similar results were observed in animal model-based studies. It raises the question of whether an increase in the number of infiltrating $B$ cells increases chronic disease duration or whether chronic inflammatory lesions of the eye attract more B cells. Alternatively, it is a mutually reinforcing vicious circle that can be interrupted by B-cell depletion therapy.

Behçet disease (BD) is characterized by occlusive vasculitis and can affect many different systems. Ocular manifestations are usually bilateral non-granulomatous panuveitis and occlusive retinal vasculitis (54). Several studies reported uveitis in 43$65 \%$ of patients with BD (58). In most cases, B cells, plasma cells, and antibodies can be found in the aqueous humor and ocular tissue in patients with $\mathrm{BD}$, although $\mathrm{T}$ cells always outnumbered $B$ cells $(56,57)$. In serum, a modified B cell function has been reported in patients with active $\mathrm{BD}$. Although the total CD19+ B number was unchanged, activated and memory $B$ cell subsets as well as spontaneous immunoglobulin(Ig)-secreting B cells increased (59). However, another study found B cells in serum was less in patients than in controls, mostly due to decreased CD27+ memory B cells expressing IgM, IgG and IgA (77). The relocation of memory $\mathrm{B}$ cells into the site of inflammation may account for the deviation found in the blood, since the demonstrated abundance of B cells in the inflammation (77). Serum immunoglobulin levels are also elevated (58). Gene expression profiling of peripheral blood cells also indicated that $\mathrm{B}$ cells activated and produced autoantibodies during BD $(60,61)$. However, whether elevated circulating antibodies and abnormal B cells in serum are associated with ocular manifestation are indeterminate. Comparative tests between patients with $\mathrm{BD}$ with or without uveitis may help to answer this question.

In other clinical entities of uveitis, evidence of B-cell participation is rare and derived from earlier research. As observed in eyes with $\mathrm{BD}$, immunohistochemical studies showed the predominance of $\mathrm{T}$ cells and the presence of a relatively fewer number of B cells and plasma cells in ocular infiltrates of patients with VKH $(62,63)$, sarcoidosis (65), and idiopathic uveitis (66). In patients with $\mathrm{VKH}$, serum autoantibodies against gangliosides, outer segments of the photoreceptors, and Müller cells have been detected (64). Limited data are available on multifocal choroiditis, which show that infiltrating $\mathrm{B}$ cells outnumbered $\mathrm{T}$ cells in inflammatory sites $(67,68)$. In patients with Fuchs' heterochromic cyclitis, oligoclonal IgG bands were found in the aqueous humor but not in the serum, suggesting the intraocular production of IgG with restricted specificity (69). However, the significance of the IgG bands is still unknown.

\section{Comparison of B-Cell Participation in Diverse Non-Infectious Uveitides}

We have provided evidence of B-cell participation in EAU and several common human non-infectious uveitides in terms of the number of B cells and plasma cells infiltrating the ocular tissue; antibodies found in eyes; gene and protein expression profiles of $\mathrm{B}$ cells; and serum components including changes in the numbers of peripheral B cells and antibodies. From these data, diverse B-cell participation in different cases of non-infectious uveitis can be concluded. In most cases, B cells play a minor role in EAU, but exceptions still exist. In human non-infectious uveitis, B cells seem to highly contribute to the pathogenic mechanisms of JIAU, SO, and multifocal choroiditis. Particularly in JIAU, strong evidence confirmed the pro-inflammatory functions of B cells in uveitis by producing antibodies. In other human non-infectious uveitides, B cells appear to play a minor role in the pathogenesis. However, as the number of cases in each experiment is relatively small and the accessible ocular tissue is usually derived from advanced diseases, 
it is difficult to draw a precise conclusion, especially regarding the onset of the disease.

Several comparative tests have also explored this subject. A report revealed that the number of CD19+ B cells in the aqueous humor derived from patients with idiopathic uveitis (including anterior uveitis and panuveitis) is lower than that in patients with systemic disease-associated uveitis (including ankylosing spondylitis, sarcoidosis, Behçet's disease) (70). Two experiments compared the involvement of B cells in granulomas and non-granulomas uveitis by analyzing B cell-associated molecules. BAFF and a proliferation-inducing ligand (APRIL) are survival factors of B cells and plasma cells $(78,79)$. B cell chemoattractant CXCL13 can attract B cells and follicular helper $\mathrm{T}$ cells to form ectopic lymphoid structures (ELSs) (80, 81). Levels of APRIL, BAFF, and CXCL13 were significantly higher in aqueous humor samples collected from patients with active uveitis than in healthy controls (CXCL13 was not detected) (41, 71) suggesting that $B$ cells are involved in the pathogenesis of uveitis. Additionally, APRIL and CXCL13 levels were significantly higher in patients with granulomatous uveitis (sarcoidosis and $\mathrm{VKH}$ ) than in patients with non-granulomatous uveitis (BD and HLA-B27 associated anterior uveitis) $(41,42,71)$. These higher levels of molecules suggest that B cells may be pathogenetically more important in granulomatous uveitis (42). This hypothesis has a limited application scope. The participation of B cells in SO, usually granulomatous uveitis, confirmed it, whereas it was inconsistent with the high involvement of B cells in JIAU, usually non-granulomatous uveitis. Notably, even in the same uveitis subtype, the participation of B cells may change with the disease duration, as discussed in EAU and SO. Predominance of B cells tends to correlate with a long disease duration.

Overall, B-cell participation in non-infectious uveitis differs on a case-to-case basis. Identifying the types of uveitides that show high $\mathrm{B}$ cell participation may be beneficial for selecting patients suffering from refractory non-infectious uveitis for B-cell depletion therapy or other biologics targeting B-cell-related molecules. According to the concrete mechanisms of B-cell participation, the elevated antibodies found in the ocular tissues or sera of patients with non-infectious uveitis demonstrate that B cells promote inflammation in patients by producing antibodies. However, other mechanisms of B cell-participation in noninfectious uveitis are not shown by the above evidence. This will be discussed in detail in the subsequent section.

\section{B CELLS PLAY MULTIPLE ROLES IN AUTOIMMUNITY AND NON- INFECTIOUS UVEITIS}

B cells have been viewed as central contributors to autoimmunity because of their ability to produce antibodies (40). The antibodyindependent functions of $\mathrm{B}$ cells have received attention after clinical trials supported the efficacy of rituximab in several autoimmune diseases, including those considered to primarily involve T cells $(82,83)$. Rituximab is an anti-CD20 monoclonal antibody (84) and has no major effect on immunoglobulin production because plasma cells do not express CD20 (85-87). B cells can also help develop ectopic lymphoid-like structures conducive to antibody production. Moreover, a group of regulatory B cells (Bregs), which can inhibit inflammation, have recently captured researchers' attention (88). Many studies have identified multiple functions of $B$ cells in various autoimmune diseases. In non-infectious uveitis, these functions of B cells were also evident. Hence, we will discuss the multiple functions of B cells in autoimmunity and highlight their roles in non-infectious uveitis in this part.

\section{B Cells Promote Inflammation by Producing Autoantibodies}

Autoantibodies produced by plasma cells promote inflammation in multiple ways, as reviewed in other studies $(89,90)$ : autoantibodies lead to direct cell lysis; antigen-antibody immune complexes that are deposited in organs or tissues, activate complements and Fc receptor-bearing leukocytes including granulocytes and macrophages to extend inflammation; binding of autoantibodies to receptors on cell surfaces could block or excessively upregulate their functions. These mechanisms have been found in many autoimmune diseases such as systemic lupus erythematosus (SLE), autoimmune hemolytic anemia, and Grave's disease.

In non-infectious uveitis, the existence of autoantibodies against ocular tissues has been confirmed in several different uveitides. Especially in JIAU, autoantibodies were found both in the eye and in the bloodstream. Antibodies cannot pass through the complete blood-eye barrier (73). Thus, antibodies in the circulation may impair ocular tissue only after the diseases are established and the blood-eye barrier is broken. In addition, antibodies produced locally may function earlier. The proinflammatory function of antibodies was verified by the study that transferred $\mathrm{T}$ cells with immune serum as alluded earlier. However, the above study did not demonstrate the mechanism of inflammation during non-infectious uveitis. We hypothesized that antibodies that promote inflammation, as evidenced in other autoimmune diseases, also exist in non-infectious uveitis. More research is needed to explore the concrete mechanisms of how antibodies function during non-infectious uveitis.

\section{B Cells Regulate T Cell Response via Their Autoantibody-Independent Function}

$\mathrm{B}$ cells can regulate the proliferation and differentiation of $\mathrm{T}$ cells via antigen presentation, co-stimulation, and cytokine secretion. $\mathrm{B}$ cells present antigens to T cells via major histocompatibility complex (MHC)-I or II (91) and express costimulatory molecules, including CD80, CD86, and CD40 (92, 93). These two functions have been proven using genetically engineered mice with autoimmune diseases, in which only B cells lack MHC-II molecules or costimulatory molecules. In these mice, autoantigen-induced disease establishment was abrogated, T cell clonal expansion was significantly reduced, and the differentiation of $\mathrm{T}$ cells into cytokine-secreting effector $\mathrm{T}$ cells and memory $\mathrm{T}$ cells was impaired $(94,95)$. T cells from these mice lost the capacity to transfer autoimmune disease (93). As cytokine-producers, B cells produce proinflammatory cytokines 
such as TNF- $\alpha$, IFN- $\gamma$, IL-6, and IL-12 (96). B cells have been identified as major producers of IL- 6 in disease models for systemic lupus erythematosus (SLE) and multiple sclerosis (MS) $(97,98)$. In vitro experiments also implied that B cells can produce GM-CSF to activate myeloid cells (99). These cytokines can influence the activities of various cells, including T cells (100). B cells modulating T cell response via antibodyindependent pathways is also indirectly proven by decreased tissue CD4 T cell numbers (101), Th1/Th17 responses, and increased regulatory $\mathrm{T}$ cell (Treg) numbers (102) after rituximab treatment in several autoimmune diseases.

With regard to non-infectious uveitis, rituximab has been shown to be effective in patients with chronic anterior uveitis (103), refractory Behçet disease-associated uveitis (104), JIA (105, 106), VKH (11, 107, 108), multifocal choroiditis (109), and other more rare uveitides (110). The patients involved in these case reports or case series mainly developed severe uveitis with prolonged disease duration and resistance to topical and systemic corticosteroids, immunosuppressors, TNF- $\alpha$ inhibitors, or other biologics. Resistance to some of the classical drugs and the response to rituximab indirectly suggest that B cells participate in the pathogenesis of non-infectious uveitis in autoantibodyindependent ways, particularly in the late phase of diseases. However, it is difficult to discuss how B cells participate in the onset of the disease since rituximab is not administered to patients with new-onset non-infectious uveitis. Additionally, the efficacy studies of rituximab only demonstrate its overall autoantibodyindependent function; specific functions involving antigen presentation, co-stimulation, and cytokine secretion have still not been extensively studied. Corresponding studies on preclinical models for non-infectious uveitis are lacking. We can refer to studies conducted on other autoimmune diseases that induce EAU in mice in which only B cells lack MHC-II molecules or costimulatory molecules. In this way, we may obtain more direct evidence and explore the autoantibody-independent function of B cells at the onset of the disease.

\section{B Cells Constitute ELSs}

ELSs, also called tertiary lymphoid organs, are structurally and functionally similar to secondary lymphoid organs $(111,112)$. ELSs can develop within chronic inflamed organs such as the joints of patients with rheumatoid arthritis (RA) (113) and the central nervous system of patients with MS (114). ELSs mainly consists of B cells (112). It contains anatomically distinct but adjacent $\mathrm{B}$ and $\mathrm{T}$ cell areas and germinal centers where $\mathrm{T}$ follicular helper cells (Tfh) and follicular dendritic cells (FDC) help B cells develop into long-living plasma cells and generate antibodies $(111,115)$. In most cases, ELSs are associated with a severe disease and local production of autoantibodies (116-118).

ELSs were first reported in three out of 11 patients with chronic non-infectious uveitis 4 years ago (66). In addition to B cells, follicular B cells, macrophages, and plasma cells are components of ELSs (66). ELSs were also found in experimental models $(45,119,120)$. In IRBP TCR transgenic $\mathrm{R} 161 \mathrm{H}$ mice, approximately $40 \%$ of mice developed ELSs. More detailed cell composition was characterized in this experimental model; ELSs were found to comprise approximately 30\% CD4+
T cells, $10 \%$ CD8+ T cells, and $60 \%$ B220+ B cells. CD138+/ B220+ plasma cells were found in large well-developed ELSs, which usually occurs in the late stage of the disease (120). The function of ELSs in ocular tissue is poorly understood. In the same experimental model, when ELSs spread out, increased loss of visual function occurred in mice. In addition, mice with ELSs had higher levels of serum antibodies against IRBP than did those without ELSs. These may result from the local generation of autoantibodies by plasma cells in the well-developed ELSs (120). Overall, B cells constitute ELSs, which may contribute to an increase in the severity of the disease and local production of autoantibodies in non-infectious uveitis.

\section{B cells Inhibit Autoimmunity Prominently by Secreting Anti-Inflammatory Cytokines}

In the past two decades, regulatory $\mathrm{B}$ cells (Bregs) have been identified as suppressive components of autoimmunity (40). Bregs are relatively rare and account for less than $10 \%$ of $\mathrm{B}$ cells in circulation in healthy people (121). Although there is no unique surface marker that exclusively identifies Bregs, most of them express CD24, CD1d, CD38, and CD5 (122-124). They possess the same feature of suppressing immune responses dominantly via secretion of IL-10; thus, the secretion of IL-10 serves as a marker of Bregs (40). In addition to IL-10, IL-35 has been recognized as another key immunoregulatory cytokine produced by Bregs (88). IL-10 and IL-35 suppress inflammation by several mechanisms, including inhibition of Th1, Th17, and monocytes secreting INF- $\gamma$, IL-17, and TNF- $\alpha$ and promoting the generation of Tregs (125, 126). In particular, IL-35 can induce Bregs generation and ultimately promote IL-10 and IL-35 production (126). Furthermore, B cells could regulate autoimmunity via upregulating the inhibitory receptor Programmed Cell DeathLigand 1 (PD-L1) (127) or killing CD4+ T cells by FasL/Fasdependent mechanisms (128).

In non-infectious uveitis, using flow cytometry analysis, Bregs were found in the retina during EAU and surprisingly accounted for $>40 \%$ of all B cells detected (46). This proportion was much higher than that in peripheral blood, which was reported to be $10 \%$, and was close to half of all B cells, suggesting that Bregs are positively recruited into the ocular inflammation and that the regulatory function is an important component of B-cell participation in non-infectious uveitis. The functions of IL-10 and IL-35 were also confirmed in non-infectious uveitis. Neutralization of IL-10 with antibody exacerbated EAU and overexpression of IL-10 in the eye ameliorated uveitis (129). Recombinant IL-35 (rIL-35)-treated mice showed mild EAU with an increase in the number of Bregs and IL-35 producing Bregs (i35-Bregs), indicating that IL-35 could suppress uveitis by inducing the expansion of Bregs and i35-Bregs (130). Human recombinant IL-35 inhibited IL-17 and IFN- $\gamma$ production and induced IL-10 production in peripheral blood mononuclear cells (PBMCs) when co-cultured with PBMCs from patients with VKH (131). Moreover, Bregs, but not Tregs or myeloid cells producing major IL-10 and IL-35 during EAU, have been demonstrated using flow cytometry and intracellular cytokine staining assays (46). It is tempting to speculate that Bregs, but not Tregs, are the major regulatory component during non-infectious uveitis. 
Overall, B cells play multiple roles in autoimmunity, and these functions have also been verified in non-infectious uveitis (Figure 2).

\section{HOW RITUXIMAB WORKS IN NON-INFECTIOUS UVEITIS}

B-cell participation in non-infectious uveitis can be separated into two parts: anti-inflammatory and pro-inflammatory components. Rituximab has no major effect on immunoglobulin production. It may work by eliminating the antibody-independent function of $\mathrm{B}$ cells, including promoting the $\mathrm{T}$ cell response via antigen presentation, co-stimulation, and cytokine secretion. Rituximab can also abrogate the establishment of ELSs. However, at the same time, Bregs, the pivotal regulatory components in uveitis, are also eliminated. There is a possibility interpretation for this. The quantity and function of Bregs are adversely affected during non-infectious uveitis. The number of Bregs decreased in the peripheral blood of patients with SLE (123), RA (132), and some other autoimmune diseases $(133,134)$. In patients with SLE, Bregs produced low levels of IL-10 in response to CD40 and were unable to inflict the Th1 reaction (123). Injured Bregs function was also found in patients with MS (135). Reduced serum levels of IL-35 in patients with active VKH (131)and patients with BD partly confirmed this scenario (136). Repopulation of B cells after Bcell depletion therapy has been reported in patients with neuromyelitis optica (135), RA (137), and pemphigus (138). In neuromyelitis, after rituximab treatment, most circulating B cells were removed. After 6 months, B cells reemerged, and the majority showed the naïve CD27 negative phenotype [CD27 is present on the surface of memory B cells and antibody-secreting B cells (139)]. Newly developed B cells secreted increased levels of IL-10 and decreased levels of lymphotoxin, suggesting that B cells changed toward a more naïve phenotype with a restored Bregs quantity as well as function (135). Therefore, rituximab may also work by restoring the quantity and function of Bregs in noninfectious uveitis. There are other regulatory B cell populations with high resistance to anti-CD20 antibodies. IL-10-producing plasmablasts (140) lack CD20. Bregs expressing high levels of
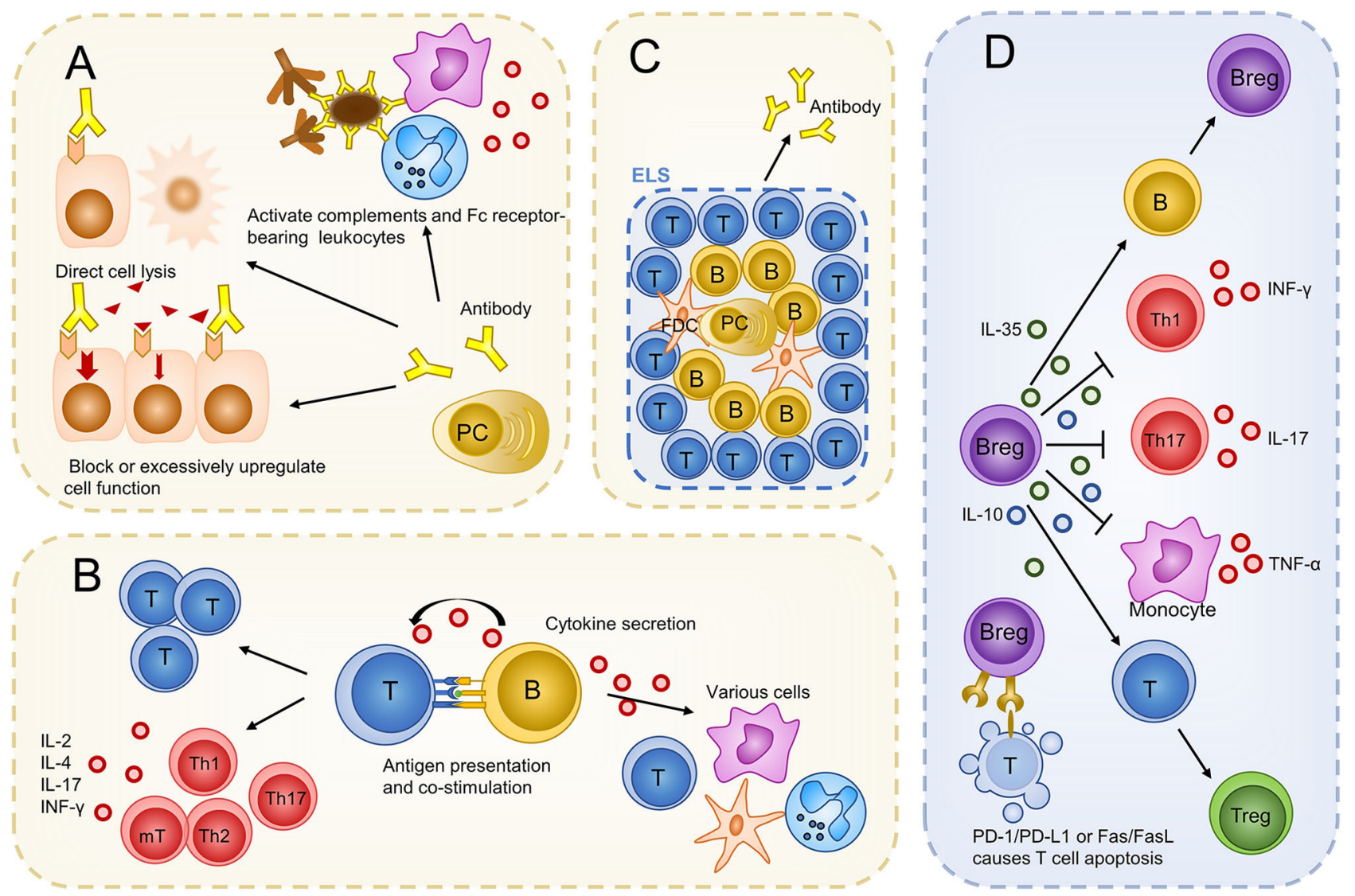

FIGURE 2 Possible roles of B cells in non-infectious uveitis. B cells evolve into plasma cells and produce antibodies to promote inflammation and damage ocular tissues (A). Via antibody independent functions, B cells regulate the proliferation and differentiation of T cells. Cytokines produced by B cells can also influence other immune cells (B). B cells constitute ELS to produce more autoantibodies (C). Bregs regulate immunity mainly by producing IL-10 and IL-35. Bregs can also kill T cells via a PD-1/PD-L1 or Fas/FasL-dependent mechanism (D). PC, plasma cell; T, T cell; B, B cell; mT, memory T cell; Th, T helper cell; FDC, follicular dendritic cell; Tfh, follicular helper T cell; ELS, ectopic lymphoid structures; IL, interleukin; PD-L1, programmed cell death-ligand 1. 
PD-L1 also resist anti-20 therapy primarily due to their high levels of BAFF receptor (BAFF-R) expression (141). The efficacy of rituximab against uveitis may partly come from the expansion of these resistant regulatory $\mathrm{B}$ cells. Overall, in addition to eliminating effector $\mathrm{B}$ cells that can promote $\mathrm{T}$ cell response, rituximab may also restore Bregs quantity and function during non-infectious uveitis (Figure 3).

\section{DISCUSSION}

The participation of $\mathrm{B}$ cells in non-infectious uveitis has been ascertained by increasing evidence from animal models and several human non-infectious uveitides. Significantly, B cells may participate to a great extent in the pathogenesis of some uveitis subtypes, such as JIAU, and their participation may be limited in the others, as in EAU induced in most experimental models. As in the case of autoimmunity, B cells play multiple roles in the pathogenic mechanisms of non-infectious uveitis. Rituximab is useful for treating several refractory uveitis cases. Its mechanism of action may involve the depletion of proinflammatory B cells and restoration of Bregs quantity and function at the same time.
However, there are still some unsolved questions concerning Bcell participation in non-infectious uveitis in need of future exploration. For instance, the following are unclear: the time of participation of B cells in the disease, particularly, if B cells can trigger non-infectious uveitis or if they only function after inflammation has been induced by $\mathrm{T}$ cells; the relationship of $\mathrm{B}$ cells with disease duration and severity; and the ratio of the antiinflammatory function to the pro-inflammatory function of B cells during non-infectious uveitis. Clinical studies using ocular tissue or serum samples of patients are not sufficient to discuss these questions. EAU has limitation in fully representing all different human non-infectious uveitides. Thus, diversified experimental model choices could be considered in future exploration. Moreover, although histology, immunohistochemistry, and flow cytometry studies are good tools to identify immune cells in uveitis, it is difficult to use them for testing the dynamic, in vivo changes and for obtaining direct evidence of cell function. Consequently, new technologies are supposed to overcome these limitations and thus help to further ascertain B-cell engagement in non-infectious uveitis. For example, in vivo immune-cell-specific bioluminescence successfully measures the dynamic intraocular immune cell population during EAU according to the change in luminous intensity (142). Single-cell RNA sequencing is a

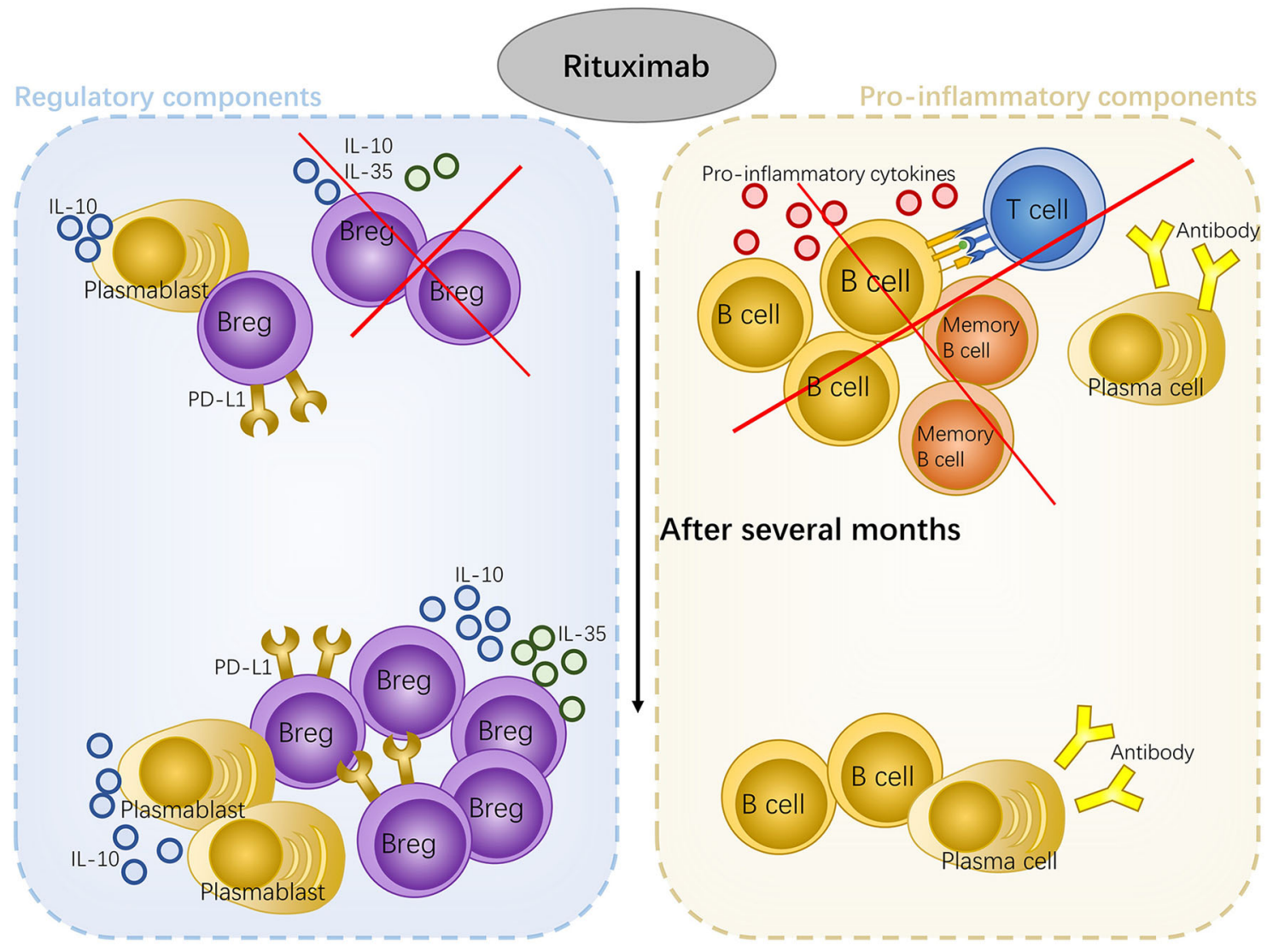

FIGURE 3 | The mechanism of rituximab treatment in uveitis. Rituximab eliminates effector B cells and malfunctioning Bregs as well as induces the restoration of the quantity and function of Bregs. Some regulatory B cell lines resistant to rituximab also expand and contribute to the efficacy of this drug. 
comprehensive and unbiased approach to investigate cell types and provide information about the function of lymphocytes by analyzing gene expression patterns during non-infectious uveitis (45).

Finally, identifying the participation levels of B cells and their function is conducive for guiding B-cell depletion therapy and for using more targeting biologics in non-infectious uveitis as well as in other autoimmune diseases. Aside from depleting B cells directly, therapies that enhance the function of Bregs as well as drugs that target B cell associated molecules such as BAFF, APRIL and CXCL13 (108) should also be considered in future studies.

\section{REFERENCES}

1. Sève P, Cacoub P, Bodaghi B, Trad S, Sellam J, Bellocq D, et al. Uveitis: Diagnostic Work-Up. A Literature Review and Recommendations From an Expert Committee. Autoimmun Rev (2017) 16:1254-64. doi: 10.1016/ j.autrev.2017.10.010

2. Miserocchi E, Fogliato G, Modorati G, Bandello F. Review On the Worldwide Epidemiology of Uveitis. Eur J Ophthalmol (2013) 23:705-17. doi: 10.5301/ejo.5000278

3. Tsirouki T, Dastiridou A, Symeonidis C, Tounakaki O, Brazitikou I, Kalogeropoulos C, et al. A Focus on the Epidemiology of Uveitis. Ocul Immunol Inflammation (2018) 26:2-16. doi: 10.1080/09273948.2016.1196713

4. Prete M, Dammacco R, Fatone MC, Racanelli V. Autoimmune Uveitis: Clinical, Pathogenetic, and Therapeutic Features. Clin Exp Med (2016) 16:125-36. doi: 10.1007/s10238-015-0345-6

5. Bermejo I, Squires H, Poku EN, Cooper K, Stevens JW, Hamilton J, et al. Adalimumab for Non-Infectious Uveitis: Is it Cost-Effective? Br J Ophthalmol (2019) 103:1633-8. doi: 10.1136/bjophthalmol-2018-312756.

6. Foster CS, Kothari S, Anesi SD, Vitale AT, Chu D, Metzinger JL, et al. The Ocular Immunology and Uveitis Foundation Preferred Practice Patterns of Uveitis Management. Surv Ophthalmol (2016) 61:1-17. doi: 10.1016/ j.survophthal.2015.07.001

7. Smith JR, Stempel AJ, Bharadwaj A, Appukuttan B. Involvement of B Cells in Non-Infectious Uveitis. Clin Trans Immunol (2016) 5:e63. doi: 10.1038/ cti. 2016.2

8. Amadi-Obi A, Yu C, Liu X, Mahdi RM, Clarke GL, Nussenblatt RB, et al. Th17 Cells Contribute to Uveitis and Scleritis and are Expanded by IL-2 and Inhibited by IL-27/STAT1. Nat Med (2007) 13:711-8. doi: 10.1038/nm1585

9. Baker KP, Edwards BM, Main SH, Choi GH, Wager RE, Halpern WG, et al. Generation and Characterization of LymphoStat-B, a Human Monoclonal Antibody That Antagonizes the Bioactivities of B Lymphocyte Stimulator. Arthritis Rheum (2003) 48:3253-65. doi: 10.1002/art.11299

10. Carnahan J, Stein R, Qu Z, Hess K, Cesano A, Hansen HJ, et al. Epratuzumab, a CD22-targeting Recombinant Humanized Antibody With a Different Mode of Action From Rituximab. Mol Immunol (2007) 44:133141. doi: 10.1016/j.molimm.2006.05.007

11. Umran RMR, Shukur ZYH. Rituximab for Sight-Threatening Refractory Pediatric Vogt-Koyanagi-Harada Disease. Mod Rheumatol (2018) 28:197-9. doi: 10.3109/14397595.2015.1071234

12. Pelegrin L, Jakob E, Schmidt-Bacher A, Schwenger V, Becker M, Max R, et al. Experiences With Rituximab for the Treatment of Autoimmune Diseases With Ocular Involvement. J Rheumatol (2014) 41:84-90. doi: 10.3899/ jrheum.130206

13. Airody A, Heath G, Lightman S, Gale R. Non-Infectious Uveitis: Optimising the Therapeutic Response. Drugs (2016) 76:27-39. doi: 10.1007/s40265-0150502-y

14. Tsirouki T, Dastiridou A, Symeonidis C, Tounakaki O, Brazitikou I, Kalogeropoulos C, et al. A Focus on the Epidemiology of Uveitis. Ocul Immunol Inflammation (2016) 26:2-16. doi: 10.1080/09273948.2016.1196713

15. Sève P, Kodjikian L, Adélaïde L, Jamilloux Y. Uveitis in Adults: What Do Rheumatologists Need to Know? Joint Bone Spine (2015) 82:308-14. doi: 10.1016/j.jbspin.2015.06.002

\section{AUTHOR CONTRIBUTIONS}

Conception and design: WS. Drafting and revising of the article: WS, LZ, and BC. Final approval: WS. All authors contributed to the article and approved the submitted version.

\section{FUNDING}

This work was supported by the National Key Research and Development Program of China (2017YFA0105804).

16. Caspi RR. A Look at Autoimmunity and Inflammation in the Eye. J Clin Invest (2010) 120:3073-83. doi: 10.1172/JCI42440

17. Schwartzman S. Advancements in the Management of Uveitis. Best Pract Res Clin Rheumatol (2016) 30:304-15. doi: 10.1016/j.berh.2016.07.005

18. Nalcacioglu-Yuksekkaya P, Ozdal PC, Yazici A, Tirhis H. Clinical and Demographic Characteristics of Patients With Uveitis Starting Later in Life. Ocul Immunol Inflammation (2015) 23:304-10. doi: 10.3109/ 09273948.2014.938761

19. Nguyen QD, Merrill PT, Sepah YJ, Ibrahim MA, Banker A, Leonardi A, et al. Intravitreal Sirolimus for the Treatment of Noninfectious Uveitis: Evolution Through Preclinical and Clinical Studies. Ophthalmology (2018) 125:198493. doi: 10.1016/j.ophtha.2018.06.015

20. Dick AD, Forrester JV, Liversidge J, Cope AP. The Role of Tumour Necrosis Factor (TNF-Alpha) in Experimental Autoimmune Uveoretinitis (Eau). Prog Retin Eye Res (2004) 23:617-37. doi: 10.1016/j.preteyeres.2004.06.005

21. Sharma SM, Nestel AR, Lee RWJ, Dick AD. Clinical Review: Anti-Tnfalpha Therapies in Uveitis: Perspective On 5 Years of Clinical Experience. Ocul Immunol Inflammation (2009) 17:403-14. doi: 10.3109/09273940903072443

22. Calvo-Río V, Santos-Gómez M, Calvo I, González-Fernández MI, López-Montesinos B, Mesquida M, et al. Anti-Interleukin-6 Receptor Tocilizumab for Severe Juvenile Idiopathic Arthritis-Associated Uveitis Refractory to Anti-Tumor Necrosis Factor Therapy: A Multicenter Study of Twenty-Five Patients. Arthritis Rheumatol (Hoboken NJ) (2017) 69:66875. doi: 10.1002/art.39940

23. Atienza-Mateo B, Calvo-Río V, Beltrán E, Martínez-Costa L, Valls-Pascual E, Hernández-Garfella M, et al. Anti-Interleukin 6 Receptor Tocilizumab in Refractory Uveitis Associated With Behçet's Disease: Multicentre Retrospective Study. Rheumatol (Oxford England) (2018) 57:856-64. doi: 10.1093/rheumatology/kex480

24. Pepple KL, Wilson L, Van Gelder RN. Comparison of Aqueous and Vitreous Lymphocyte Populations From Two Rat Models of Experimental Uveitis. Invest Opthalmol Visual Sci (2018) 59:2504. doi: 10.1167/iovs.1824192

25. Pennesi G, Mattapallil MJ, Sun S, Avichezer D, Silver PB, Karabekian Z, et al. A Humanized Model of Experimental Autoimmune Uveitis in HLA Class II Transgenic Mice. J Clin Invest (2003) 111:1171-80. doi: 10.1172/JCI15155

26. Bansal S, Barathi VA, Iwata D, Agrawal R. Experimental Autoimmune Uveitis and Other Animal Models of Uveitis: An Update. Indian J Ophthalmol (2015) 63:211-8. doi: 10.4103/0301-4738.156914

27. Caspi RR. Th1 and Th2 Responses in Pathogenesis and Regulation of Experimental Autoimmune Uveoretinitis. Int Rev Immunol (2002) 21:197208. doi: 10.1080/08830180212063

28. Bose T, Diedrichs-Möhring M, Wildner G. Dry Eye Disease and Uveitis: A Closer Look at Immune Mechanisms in Animal Models of Two Ocular Autoimmune Diseases. Autoimmun Rev (2016) 15:1181-92. doi: 10.1016/ j.autrev.2016.09.001

29. Epps SJ, Boldison J, Stimpson ML, Khera TK, Lait PJP, Copland DA, et al. Re-Programming Immunosurveillance in Persistent non-Infectious Ocular Inflammation. Prog Retin Eye Res (2018) 65:93-106. doi: 10.1016/ j.preteyeres.2018.03.001

30. Wildschütz L, Ackermann D, Witten A, Kasper M, Busch M, Glander S, et al. Transcriptomic and Proteomic Analysis of Iris Tissue and Aqueous Humor 
in Juvenile Idiopathic Arthritis-Associated Uveitis. J Autoimmun (2019) 100:75-83. doi: 10.1016/j.jaut.2019.03.004

31. Luger D, Silver PB, Tang J, Cua D, Chen Z, Iwakura Y, et al. Either a Th17 or a Th1 Effector Response can Drive Autoimmunity: Conditions of Disease Induction Affect Dominant Effector Category. J Exp Med (2008) 205:799810. doi: $10.1084 /$ jem. 20071258

32. Dick AD, Forrester JV, Liversidge J, Cope AP. The Role of Tumour Necrosis Factor (TNF-Alpha) in Experimental Autoimmune Uveoretinitis (Eau). Prog Retin Eye Res (2004) 23:617-37. doi: 10.1016/j.preteyeres.2004.06.005

33. Namba K, Kitaichi N, Nishida T, Taylor AW. Induction of Regulatory $\mathrm{T}$ Cells by the Immunomodulating Cytokines Alpha-Melanocyte-Stimulating Hormone and Transforming Growth Factor-Beta2. J Leukocyte Biol (2002) 72:946-52. doi: 10.1189/jlb.72.5.946

34. Su SB, Grajewski RS, Luger D, Agarwal RK, Silver PB, Tang J, et al. Altered Chemokine Profile Associated With Exacerbated Autoimmune Pathology Under Conditions of Genetic Interferon-Gamma Deficiency. Invest Ophth Vis Sci (2007) 48:4616-25. doi: 10.1167/iovs.07-0233

35. Dick AD, Tugal-Tutkun I, Foster S, Zierhut M, Melissa Liew SH, Bezlyak V, et al. Secukinumab in the Treatment of Noninfectious Uveitis: Results of Three Randomized, Controlled Clinical Trials. Ophthalmology (2013) 120:777-87. doi: 10.1016/j.ophtha.2012.09.040

36. Parikh JG, Tawansy KA, Rao NA. Immunohistochemical Study of Chronic Nongranulomatous Anterior Uveitis in Juvenile Idiopathic Arthritis. Ophthalmology (2008) 115:1833-6. doi: 10.1016/j.ophtha.2008.03.027

37. Shah DN, Piacentini MA, Burnier MN, McLean IW, Nussenblatt RB, Chan CC. Inflammatory Cellular Kinetics in Sympathetic Ophthalmia a Study of 29 Traumatized (Exciting) Eyes. Ocul Immunol Inflammation (1993) 1:25562. doi: $10.3109 / 09273949309085026$

38. Fujino Y, Li Q, Chung H, Hikita N, Nussenblatt RB, Gery I, et al. Immunopathology of Experimental Autoimmune Uveoretinitis in Primates. Autoimmunity (1992) 13:303-9. doi: 10.3109/08916939209112339

39. Eibel H, Kraus H, Sic H, Kienzler A, Rizzi M. B Cell Biology: An Overview. Curr Allergy Asthm R (2014) 14:434. doi: 10.1007/s11882-014-0434-8

40. Mauri C, Bosma A. Immune Regulatory Function of B Cells. Annu Rev Immunol (2012) 30:221-41. doi: 10.1146/annurev-immunol-020711-074934

41. Abu El-Asrar AM, Berghmans N, Al-Obeidan SA, Mousa A, Opdenakker G, Van Damme J, et al. The Cytokine Interleukin-6 and the Chemokines CCL20 and CXCL13 are Novel Biomarkers of Specific Endogenous Uveitic Entities. Invest Ophth Vis Sci (2016) 57:4606-13. doi: 10.1167/iovs.16-19758

42. El-Asrar AMA, Berghmans N, Al-Obeidan SA, Gikandi PW, Opdenakker G, Van Damme J, et al. Differential CXC and CX3C Chemokine Expression Profiles in Aqueous Humor of Patients With Specific Endogenous Uveitic Entities. Invest Ophth Vis Sci (2018) 59:2222-8. doi: 10.1167/iovs.17-23225

43. Maruyama K, Inaba T, Sugita S, Ichinohasama R, Nagata K, Kinoshita S, et al. Comprehensive Analysis of Vitreous Specimens for Uveitis Classification: A Prospective Multicentre Observational Study. BMJ Open (2017) 7:e14549. doi: 10.1136/bmjopen-2016-014549

44. Boldison J, Chu CJ, Copland DA, Lait PJP, Khera TK, Dick AD, et al. TissueResident Exhausted Effector Memory Cd8+ T Cells Accumulate in the Retina During Chronic Experimental Autoimmune Uveoretinitis. I Immunol (Baltimore Md: 1950) (2014) 192:4541-50. doi: 10.4049/jimmunol.1301390

45. Heng JS, Hackett SF, Stein-O'Brien GL, Winer BL, Williams J, Goff LA, et al. Comprehensive Analysis of a Mouse Model of Spontaneous Uveoretinitis Using Single-Cell RNA Sequencing. Proc Natl Acad Sci USA (2019) 116:26734-44. doi: 10.1073/pnas.1915571116

46. Yu CR, Choi JK, Uche AN, Egwuagu CE. Production of IL-35 by Bregs is Mediated Through Binding of BATF-IRF-4-IRF-8 Complex Toil12a Andebi3 Promoter Elements. J Leukocyte Biol (2018) 104:1147-57. doi: 10.1002/JLB.3A0218-071RRR

47. Merriam JC, Chylack LT Jr, Albert DM. Early-Onset Pauciarticular Juvenile Rheumatoid Arthritis. A Histopathologic Study. Arch Ophthalmol (1983) 105:1085-92. doi: 10.1001/archopht.1983.01040020087015

48. Godfrey WA, Lindsley CB, Cuppage FE. Localization of IgM in Plasma Cells in the Iris of a Patient with Iridocyclitis and Juvenile Rheumatoid Arthritis. Arthritis Rheum (1981) 24:1195-8. doi: 10.1002/art.1780240914

49. Kalinina Ayuso V, van Dijk MR, de Boer JH. Infiltration of Plasma Cells in the Iris of Children With ANA-Positive Anterior Uveitis. Invest Ophth Vis Sci (2015) 56:6770-8. doi: 10.1167/iovs.15-17351
50. Parikh JG, Tawansy KA, Rao NA. Immunohistochemical Study of Chronic Nongranulomatous Anterior Uveitis in Juvenile Idiopathic Arthritis. Ophthalmology (2008) 115:1833-6. doi: 10.1016/j.ophtha.2008.03.027

51. Nguyen QD, Humphrey RL, Dunn JP, Humayun MS. Elevated Vitreous Concentration of Monoclonal Immunoglobulin Manifesting as Schlieren in Juvenile Rheumatoid Arthritis-Associated Uveitis. Arch Ophthalmol (2001) 119:293-6.

52. Walscheid K, Hennig M, Heinz C, Wasmuth S, Busch M, Bauer D, et al. Correlation Between Disease Severity and Presence of Ocular Autoantibodies in Juvenile Idiopathic Arthritis-Associated Uveitis. Invest Ophth Vis Sci (2014) 55:3447-53. doi: 10.1167/iovs.13-13444

53. Amer R, Bamonte G, Forrester JV. Resolution of Juvenile Idiopathic Arthritis-Associated Uveitis After Development of Common Variable Immunodeficiency. Eur J Ophthalmol (2007) 17:666-8. doi: 10.1177/ 112067210701700429

54. Lightman S, Chan CC. Immune Mechanisms in Choroido-Retinal Inflammation in Man. Eye (London England) (1990) 4(Pt 2):345-53. doi: 10.1038/eye.1990.47

55. Aziz HA, Flynn HWJ, Young RC, Davis JL, Dubovy SR. Sympathetic OPHTHALMIA: Clinicopathologic Correlation in a Consecutive Case Series. Retina (Philadelphia Pa) (2015) 35:1696-703. doi: 10.1097/ IAE.0000000000000506

56. Yu HG, Lee DS, Seo JM, Ahn JK, Yu YS, Lee WJ, et al. The Number of CD8+ $\mathrm{T}$ Cells and NKT Cells Increases in the Aqueous Humor of Patients With Behçet's Uveitis. Clin Exp Immunol (2004) 137:437-43. doi: 10.1111/j.13652249.2004.02536.x

57. George RK, Chan C, Whitcup SM, Nussenblatt RB. Ocular Immunopathology of Behçet's Disease. United States: Elsevier Inc (1997) p. 157-62.

58. Sadreddini S, Noshad H, Molaeefard M, Noshad R. Treatment of Retinal Vasculitis in Behcet's Disease With Rituximab. Mod Rheumatol (2008) 18:306-8. doi: 10.1007/s10165-008-0057-9

59. Ekşioglu-Demiralp E, Kibaroglu A, Direskeneli H, Yavuz S, Karsli F, Yurdakul S, et al. Phenotypic Characteristics of B Cells in Behçet's Disease: Increased Activity in B Cell Subsets. J Rheumatol (1999) 26:826-32.

60. Yoon J, Lee Y, Yu S, Yoon H, Park H, Joung C, et al. Aberrant Expression of Interleukin-10 and Activation-Induced Cytidine Deaminase in B Cells From Patients With Behçet's Disease. Biomed Rep (2017) 7:520-6. doi: 10.3892/ br.2017.996

61. Inomata H, Sakamoto T. Immunohistochemical Studies of Vogt-KoyanagiHarada Disease with Sunset Sky Fundus. Curr Eye Res (1990) 9 Suppl:35-40. doi: 10.3109/0271368900899941

62. Chan CC, Palestine AG, Kuwabara T, Nussenblatt RB. Immunopathologic Study of Vogt-Koyanagi-Harada Syndrome. Am J Ophthalmol (1988) 105:607-11. doi: 10.1016/0002-9394(88)90052-9

63. Chan CC, Wetzig RP, Palestine AG, Kuwabara T, Nusenblatt RB. Immunohistopathology of Ocular Sarcoidosis. Report of a Case and Discussion of Immunopathogenesis. Arch Ophthalmol (1987) 105:1398402. doi: 10.1001/archopht.1987.01060100100036

64. Dunlop AAS, Cree IA, Hague S, Luthert PJ, Lightman S. Multifocal Choroiditis: Clinicopathologic Correlation. Arch Ophthalmol (1998) 116:801-3. doi: 10.1001/archopht.116.6.801

65. Epps SJ, Coplin N, Luthert PJ, Dick AD, Coupland SE, Nicholson LB. Features of Ectopic Lymphoid-Like Structures in Human Uveitis. Exp Eye Res (2020) 191:107901. doi: 10.1016/j.exer.2019.107901

66. Chan CC, Palestine AG, Nussenblatt RB, Roberge FG, Benezra D. AntiRetinal Auto-Antibodies in Vogt-Koyanagi-Harada Syndrome, Behcet's Disease, and Sympathetic Ophthalmia. Ophthalmology (1985) 92:1025-8. doi: 10.1016/S0161-6420(85)33911-8

67. Shimada H, Yuzawa M, Hirose T, Nakashizuka H, Hattori T, Kazato Y. Pathological Findings of Multifocal Choroiditis With Panuveitis and Punctate Inner Choroidopathy. Jpn J Ophthalmol (2008) 52:282-8. doi: 10.1007/s10384-008-0566-2

68. Murray PI, Hoekzema R, Luyendijk L, Konings S, Kijlstra A. Analysis of Aqueous Humor Immunoglobulin G in Uveitis by Enzyme-Linked Immunosorbent Assay, Isoelectric Focusing, and Immunoblotting. Invest Ophthalmol Vis Sci (1990) 31:2129-35. doi: 10.1007/BF00163567

69. Calder VL, Shaer B, Muhaya M, Mclauchlan M, Pearson RV, Jolly G, et al. Increased CD4+ Expression and Decreased Il-10 in the Anterior Chamber in 
Idiopathic Uveitis. Invest Ophth Vis Sci (1999) 40:2019-24. doi: 10.1007/ s004170050299

70. Stohl W. Therapeutic Targeting of the BAFF/APRIL Axis in Systemic Lupus Erythematosus. Expert Opin Ther Tar (2014) 18:473-89. doi: 10.1517/ 14728222.2014 .888415

71. Pescovitz MD, Greenbaum CJ, Krause-Steinrauf H, Becker DJ, Gitelman SE, Goland R, et al. Rituximab, B-lymphocyte Depletion, and Preservation of Beta-Cell Function. New Engl J Med (2009) 361:2143-52. doi: 10.1056/ NEJMoa0904452

72. Zhao J, Chen M, Xu H. Experimental Autoimmune Uveoretinitis (EAU)Related Tissue Damage and Angiogenesis is Reduced in CCL2(-)/(-)CX(3) CR1gfp/gfp Mice. Invest Ophthalmol Vis Sci (2014) 55:7572-82. doi: $10.1167 /$ iovs. $14-15495$

73. Shechter R, London A, Schwartz M. Orchestrated Leukocyte Recruitment to Immune-Privileged Sites: Absolute Barriers Versus Educational Gates. Nat Rev Immunol (2013) 13:206-18. doi: 10.1038/nri339

74. Lee JJY, Duffy CM, Guzman J, Oen K, Barrowman N, Rosenberg AM, et al. Prospective Determination of the Incidence and Risk Factors of New-Onset Uveitis in Juvenile Idiopathic Arthritis: The Research in Arthritis in Canadian Children Emphasizing Outcomes Cohort. Arthrit Care Res (2019) 71:1436-43. doi: 10.1002/acr.23783

75. Foeldvari I. Ocular Involvement in Juvenile Idiopathic Arthritis: Classification and Treatment. Clin Rev Allerg Immu (2015) 49:271-7. doi: 10.1007/s12016-014-8436-9

76. Furusato E, Shen D, Cao X, Furusato B, Nussenblatt RB, Rushing EJ, et al. Inflammatory Cytokine and Chemokine Expression in Sympathetic Ophthalmia: A Pilot Study. Histol Histopathol (2011) 26:1145-51. doi: $10.14670 / \mathrm{HH}-26.1145$

77. Puccetti A, Fiore PF, Pelosi A, Tinazzi E, Patuzzo G, Argentino G, et al. Gene Expression Profiling in Behcet's Disease Indicates an Autoimmune Component in the Pathogenesis of the Disease and Opens New Avenues for Targeted Therapy. J Immunol Res (2018) 2018:4246965. doi: 10.1155/ 2018/4246965

78. Lahiri A, Pochard P, Le Pottier L, Tobón GJ, Bendaoud B, Youinou P, et al. The Complexity of the BAFF TNF-Family Members: Implications for Autoimmunity. J Autoimmun (2012) 39:189-98. doi: 10.1016/j.jaut.2012. 05.009

79. Finch DK, Ettinger R, Karnell JL, Herbst R, Sleeman MA. Effects of CXCL13 Inhibition On Lymphoid Follicles in Models of Autoimmune Disease. Eur J Clin Invest (2013) 43:501-9. doi: 10.1111/eci.12063

80. Corsiero E, Bombardieri M, Manzo A, Bugatti S, Uguccioni M, Pitzalis C. Role of Lymphoid Chemokines in the Development of Functional Ectopic Lymphoid Structures in Rheumatic Autoimmune Diseases. Immunol Lett (2012) 145:62-7. doi: 10.1016/j.imlet.2012.04.013

81. Abu El-Asrar AM, Berghmans N, Al-Obeidan SA, Gikandi PW, Opdenakker G, Van Damme J, et al. Local Cytokine Expression Profiling in Patients With Specific Autoimmune Uveitic Entities. Ocul Immunol Inflamm (2020) 28:453-62. doi: 10.1080/09273948.2019.1604974

82. Hauser SL, Waubant E, Arnold DL, Vollmer T, Antel J, Fox RJ, et al. B-Cell Depletion With Rituximab in Relapsing-Remitting Multiple Sclerosis. New Engl J Med (2008) 358:676-88. doi: 10.1056/NEJMoa0706383

83. Thomas AS. Biologics for the Treatment of Noninfectious Uveitis. Curr Opin Ophthalmol (2019) 30:138-50. doi: 10.1097/ICU.0000000000000562

84. Pendergraft WFR, Cortazar FB, Wenger J, Murphy AP, Rhee EP, Laliberte $\mathrm{KA}$, et al. Long-Term Maintenance Therapy Using Rituximab-Induced Continuous B-Cell Depletion in Patients With ANCA Vasculitis. Clin J Am Soc Nephrol: CJASN (2014) 9:736-44. doi: 10.2215/CJN.07340713

85. Cornec D, Avouac J, Youinou P, Saraux A. Critical Analysis of RituximabInduced Serological Changes in Connective Tissue Diseases. Autoimmun Rev (2009) 8:515-9. doi: 10.1016/j.autrev.2009.01.007

86. Perosa F, Favoino E, Caragnano MA, Prete M, Dammacco F. Cd20: A Target Antigen for Immunotherapy of Autoimmune Diseases. Autoimmun Rev (2005) 4:526-31. doi: 10.1016/j.autrev.2005.04.004

87. Rosser EC, Mauri C. Regulatory B Cells: Origin, Phenotype, and Function. Immunity (2015) 42:607-12. doi: 10.1016/j.immuni.2015.04.005

88. Getahun A, Cambier JC. Non-Antibody-Secreting Functions of B Cells and Their Contribution to Autoimmune Disease. Annu Rev Cell Dev Bi (2019) 35:337-56. doi: 10.1146/annurev-cellbio-100617-062518
89. Ludwig RJ, Vanhoorelbeke K, Leypoldt F, Kaya Z, Bieber K, McLachlan SM, et al. Mechanisms of Autoantibody-Induced Pathology. Front Immunol (2017) 8:603. doi: 10.3389/fimmu.2017.00603

90. Claes N, Fraussen J, Stinissen P, Hupperts R, Somers V. B Cells are Multifunctional Players in Multiple Sclerosis Pathogenesis: Insights From Therapeutic Interventions. Front Immunol (2015) 6:642. doi: 10.3389/ fimmu.2015.00642

91. Linton P, Bautista B, Biederman E, Bradley ES, Harbertson J, Kondrack RM, et al. Costimulation Via Ox401 Expressed by B Cells is Sufficient to Determine the Extent of Primary Cd4 Cell Expansion and Th2 Cytokine Secretion In Vivo. J Exp Med (2003) 197:875-83. doi: 10.1084/jem.20021290

92. O’Neill SK, Cao Y, Hamel KM, Doodes PD, Hutas G, Finnegan A. Expression of CD80/86 on B Cells is Essential for Autoreactive T Cell Activation and the Development of Arthritis. J Immunol (Baltimore Md: 1950) (2007) 179:5109-16. doi: 10.4049/jimmunol.179.8.5109

93. Crawford A, Macleod M, Schumacher T, Corlett L, Gray D. Primary T Cell Expansion and Differentiation in Vivo Requires Antigen Presentation by B Cells. J Immunol (Baltimore Md: 1950) (2006) 176:3498-506. doi: 10.4049/ jimmunol.176.6.3498

94. Molnarfi N, Schulze-Topphoff U, Weber MS, Patarroyo JC, Prod'homme T, Varrin-Doyer M, et al. Mhc Class II-Dependent B Cell APC Function is Required for Induction of CNS Autoimmunity Independent of MyelinSpecific Antibodies. J Exp Med (2013) 210:2921-37. doi: 10.1084/ jem.20130699

95. Lund FE, Randall TD. Effector and Regulatory B Cells: Modulators of CD4+ T Cell Immunity. Nat Rev Immunol (2010) 10:236-47. doi: 10.1038/nri2729

96. Arkatkar T, Du SW, Jacobs HM, Dam EM, Hou B, Buckner JH, et al. B CellDerived Il-6 Initiates Spontaneous Germinal Center Formation During Systemic Autoimmunity. J Exp Med (2017) 214:3207-17. doi: 10.1084/ jem. 20170580

97. Barr TA, Shen P, Brown S, Lampropoulou V, Roch T, Lawrie S, et al. B Cell Depletion Therapy Ameliorates Autoimmune Disease Through Ablation of IL-6-Producing B Cells. J Exp Med (2012) 209:1001-10. doi: 10.1084/ jem. 20111675

98. Li R, Rezk A, Miyazaki Y, Hilgenberg E, Touil H, Shen P, et al. Proinflammatory GM-CSF-Producing B Cells in Multiple Sclerosis and B Cell Depletion Therapy. Sci Transl Med (2015) 7:166r-310r. doi: 10.1126/ scitranslmed.aab4176

99. Borish LC, Steinke JW. 2. Cytokines and Chemokines. J Allergy Clin Immunol (2003) 111:S460-75. doi: 10.1067/mai.2003.108

100. Sentís A, Diekmann F, Llobell A, de Moner N, Espinosa G, Yagüe J, et al. Kinetic Analysis of Changes in T- and B-lymphocytes After Anti-CD20 Treatment in Renal Pathology. Immunobiology (2017) 222:620-30. doi: 10.1016/j.imbio.2016.11.011

101. Zhao Y, Lutalo PMK, Thomas JE, Sangle S, Choong LM, Tyler JR, et al. Circulating T Follicular Helper Cell and Regulatory T Cell Frequencies are Influenced by B Cell Depletion in Patients With Granulomatosis With Polyangiitis. Rheumatol (Oxford England) (2014) 53:621-30. doi: 10.1093/ rheumatology/ket406

102. Tappeiner C, Heinz C, Specker C, Heiligenhaus A. Rituximab as a Treatment Option for Refractory Endogenous Anterior Uveitis. Ophthalmic Res (2007) 39:184-6. doi: 10.1159/000103239

103. Davatchi F, Shams H, Rezaipoor M, Sadeghi-Abdollahi B, Shahram F, Nadji A, et al. Rituximab in Intractable Ocular Lesions of Behcet's Disease; Randomized Single-Blind Control Study (Pilot Study). Int J Rheum Dis (2010) 13:246-52. doi: 10.1111/j.1756-185X.2010.01546.x

104. Heiligenhaus A, Miserocchi E, Heinz C, Gerloni V, Kotaniemi K. Treatment of Severe Uveitis Associated With Juvenile Idiopathic Arthritis With AntiCD20 Monoclonal Antibody (Rituximab). Rheumatology (Oxford) (2011) 50:1390-4. doi: 10.1093/rheumatology/ker107

105. Miserocchi E, Modorati G, Berchicci L, Pontikaki I, Meroni P, Gerloni V. Long-Term Treatment With Rituximab in Severe Juvenile Idiopathic Arthritis-Associated Uveitis. Br J Ophthalmol (2016) 100:782-6. doi: 10.1136/bjophthalmol-2015-306790

106. Caso F, Rigante D, Vitale A, Costa L, Bascherini V, Latronico E, et al. LongLasting Uveitis Remission and Hearing Loss Recovery After Rituximab in Vogt-Koyanagi-Harada Disease. Clin Rheumatol (2015) 34:1817-20. doi: 10.1007/s10067-014-2781-1 
107. Abu El-Asrar AM, Dheyab A, Khatib D, Struyf S, Van Damme J, Opdenakker G. Efficacy of B Cell Depletion Therapy With Rituximab in Refractory Chronic Recurrent Uveitis Associated With Vogt-Koyanagi-Harada Disease. Ocul Immunol Inflammation (2020) 29:1-8. doi: 10.1080/09273948.2020.1820531

108. Cornish KS, Kuffova L, Forrester JV. Treatment of Diffuse Subretinal Fibrosis Uveitis With Rituximab. Br J Ophthalmol (2015) 99:153-4.

109. Tomkins-Netzer O, Taylor SRJ, Lightman S. Can Rituximab Induce LongTerm Disease Remission in Patients With Intra-Ocular non-Infectious Inflammation? Ophthalmologica (2013) 230:109-15. doi: 10.1159/000351426

110. Neyt K, Perros F, GeurtsvanKessel CH, Hammad H, Lambrecht BN. Tertiary Lymphoid Organs in Infection and Autoimmunity. Trends Immunol (2012) 33:297-305. doi: 10.1016/j.it.2012.04.006

111. Pipi E, Nayar S, Gardner DH, Colafrancesco S, Smith C, Barone F. Tertiary Lymphoid Structures: Autoimmunity Goes Local. Front Immunol (2018) 9:1952. doi: 10.3389/fimmu.2018.01952

112. Takemura S, Klimiuk PA, Braun A, Goronzy JJ, Weyand CM. T Cell Activation in Rheumatoid Synovium is B Cell Dependent. J Immunol (Baltimore Md: 1950) (2001) 167:4710-8. doi: 10.4049/jimmunol.167.8.4710

113. Stüve O, Eagar TN. B Cells, Antibodies, and Tertiary Lymphoid Tissue in MS Brains. Lancet Neurol (2008) 7:766-7. doi: 10.1016/S1474-4422(08)70176-5

114. Corsiero E, Delvecchio FR, Bombardieri M, Pitzalis C. B Cells in the Formation of Tertiary Lymphoid Organs in Autoimmunity, Transplantation and Tumorigenesis. Curr Opin Immunol (2019) 57:46-52. doi: 10.1016/j.coi. 2019.01.004

115. Cañete JD, Celis R, Moll C, Izquierdo E, Marsal S, Sanmartí R, et al. Clinical Significance of Synovial Lymphoid Neogenesis and its Reversal After AntiTumour Necrosis Factor Alpha Therapy in Rheumatoid Arthritis. Ann Rheum Dis (2009) 68:751-6. doi: 10.1136/ard.2008.089284

116. Magliozzi R, Howell O, Vora A, Serafini B, Nicholas R, Puopolo M, et al. Meningeal B-cell Follicles in Secondary Progressive Multiple Sclerosis Associate With Early Onset of Disease and Severe Cortical Pathology. Brain: J Neurol (2007) 130:1089-104. doi: 10.1093/brain/awm038

117. Vinuesa CG, Sanz I, Cook MC. Dysregulation of Germinal Centres in Autoimmune Disease. Nat Rev Immunol (2009) 9:845-57. doi: 10.1038/nri2637

118. Kleinwort KJH, Amann B, Hauck SM, Feederle R, Sekundo W, Deeg CA. Immunological Characterization of Intraocular Lymphoid Follicles in a Spontaneous Recurrent Uveitis Model. Invest Ophth Vis Sci (2016) 57:4504-11. doi: 10.1167/iovs.16-19787

119. Kielczewski JL, Horai R, Jittayasothorn Y, Chan C, Caspi RR. Tertiary Lymphoid Tissue Forms in Retinas of Mice With Spontaneous Autoimmune Uveitis and Has Consequences on Visual Function. J Immunol (Baltimore Md: 1950) (2016) 196:1013-25. doi: 10.4049/jimmunol.1501570

120. Alhabbab RY, Nova-Lamperti E, Aravena O, Burton HM, Lechler RI, Dorling A, et al. Regulatory B Cells: Development, Phenotypes, Functions, and Role in Transplantation. Immunol Rev (2019) 292:164-79. doi: 10.1111/imr.12800

121. Lundqvist S, Modvig S, Fischer EA, Frederiksen JL, Degn M. Frequency and Immunophenotype of IL10-producing Regulatory B Cells in Optic Neuritis. Immunology (2019) 156:259-69. doi: 10.1111/imm.13024

122. Blair PA, Noreña LY, Flores-Borja F, Rawlings DJ, Isenberg DA, Ehrenstein MR, et al. CD19(+)CD24(Hi)CD38(Hi) B Cells Exhibit Regulatory Capacity in Healthy Individuals But are Functionally Impaired in Systemic Lupus Erythematosus Patients. Immunity (2010) 32:129-40. doi: 10.1016/ j.immuni.2009.11.009

123. Bouaziz J, Yanaba K, Tedder TF. Regulatory B Cells as Inhibitors of Immune Responses and Inflammation. Immunol Rev (2008) 224:201-14. doi: 10.1111/ j.1600-065X.2008.00661.x

124. Saraiva M, O'Garra A. The Regulation of IL-10 Production by Immune Cells. Nat Rev Immunol (2010) 10:170-81. doi: 10.1038/nri2711

125. Su L, Liu X, Huang A, Xu W. Emerging Role of IL-35 in Inflammatory Autoimmune Diseases. Autoimmun Rev (2018) 17:665-73. doi: 10.1016/ j.autrev.2018.01.017

126. Zacca ER, Onofrio LI, Acosta CDV, Ferrero PV, Alonso SM, Ramello MC, et al. Pd-L1(+) Regulatory B Cells are Significantly Decreased in Rheumatoid Arthritis Patients and Increase After Successful Treatment. Front Immunol (2018) 9:2241. doi: 10.3389/fimmu.2018.02241

127. Lundy SK. Killer B Lymphocytes: The Evidence and the Potential. Inflammation Res (2009) 58:345-57. doi: 10.1007/s00011-009-0014-x
128. De Kozak Y, Thillaye-Goldenberg B, Naud M, Da Costa AV, Auriault C, Verwaerde C. Inhibition of Experimental Autoimmune Uveoretinitis by Systemic and Subconjunctival Adenovirus-Mediated Transfer of the Viral Il10 Gene. Clin Exp Immunol (2002) 130:212-23. doi: 10.1046/j.13652249.2002.01969.x

129. Wang R, Yu C, Dambuza IM, Mahdi RM, Dolinska MB, Sergeev YV, et al. Interleukin-35 Induces Regulatory B Cells That Suppress Autoimmune Disease. Nat Med (2014) 20:633-41. doi: 10.1038/nm.3554

130. Hu J, Qin Y, Yi S, Wang C, Yang J, Yang L, et al. Decreased Interleukin(IL)35 Expression is Associated With Active Intraocular Inflammation in VogtKoyanagi-Harada (Vkh) Disease. Ocul Immunol Inflamm (2019) 27:595601. doi: 10.1080/09273948.2018.1433306

131. Flores-Borja F, Bosma A, Ng D, Reddy V, Ehrenstein MR, Isenberg DA, et al. Cd19+Cd24hicd38hi B Cells Maintain Regulatory T Cells While Limiting TH1 and TH17 Differentiation. Sci Transl Med (2013) 5:123r-73r. doi: 10.1126/scitranslmed.3005407

132. Aravena O, Ferrier A, Menon M, Mauri C, Aguillón JC, Soto L, et al. Tim-1 Defines a Human Regulatory B Cell Population That is Altered in Frequency and Function in Systemic Sclerosis Patients. Arthritis Res Ther (2017) 19:8. doi: 10.1186/s13075-016-1213-9

133. Kalampokis I, Venturi GM, Poe JC, Dvergsten JA, Sleasman JW, Tedder TF. The Regulatory B Cell Compartment Expands Transiently During Childhood and is Contracted in Children With Autoimmunity. Arthritis Rheumatol (Hoboken NJ) (2017) 69:225-38. doi: 10.1002/art.39820

134. Duddy M, Niino M, Adatia F, Hebert S, Freedman M, Atkins H, et al. Distinct Effector Cytokine Profiles of Memory and Naive Human B Cell Subsets and Implication in Multiple Sclerosis. J Immunol (2007) 178:6092-9. doi: 10.4049/jimmunol.178.10.6092

135. Lopalco G, Lucherini OM, Lopalco A, Venerito V, Fabiani C, Frediani B, et al. Cytokine Signatures in Mucocutaneous and Ocular Behçet's Disease. Front Immunol (2017) 8:200. doi: 10.3389/fimmu.2017.00200

136. Adlowitz DG, Barnard J, Biear JN, Cistrone C, Owen T, Wang W, et al. Expansion of Activated Peripheral Blood Memory B Cells in Rheumatoid Arthritis, Impact of B Cell Depletion Therapy, and Biomarkers of Response. PloS One (2015) 10:e128269. doi: 10.1371/journal.pone.0128269

137. Colliou N, Picard D, Caillot F, Calbo S, Le Corre S, Lim A, et al. Long-Term Remissions of Severe Pemphigus After Rituximab Therapy are Associated With Prolonged Failure of Desmoglein B Cell Response. Sci Transl Med (2013) 5:130r-75r. doi: 10.1126/scitranslmed.3005166

138. Sanz I, Wei C, Jenks SA, Cashman KS, Tipton C, Woodruff MC, et al. Challenges and Opportunities for Consistent Classification of Human B Cell and Plasma Cell Populations. Front Immunol (2019) 10:2458. doi: 10.3389/ fimmu.2019.02458

139. Matsumoto M, Baba A, Yokota T, Nishikawa H, Ohkawa Y, Kayama H, et al. Interleukin-10-Producing Plasmablasts Exert Regulatory Function in Autoimmune Inflammation. Immunity (2014) 41:1040-51. doi: 10.1016/ j.immuni.2014.10.016

140. Khan AR, Hams E, Floudas A, Sparwasser T, Weaver CT, Fallon PG. PDL1hi B Cells are Critical Regulators of Humoral Immunity. Nat Commun (2015) 6:5997. doi: 10.1038/ncomms6997

141. John S, Rolnick K, Wilson L, Wong S, Van Gelder RN, Pepple KL. Bioluminescence for in Vivo Detection of Cell-Type-Specific Inflammation in a Mouse Model of Uveitis. Sci Rep-Uk (2020) 10:11377. doi: 10.1038/ s41598-020-68227-4

142. LeBien TW, Tedder TF. B Lymphocytes: How They Develop and Function. Blood (2008) 112:1570-80. doi: 10.1182/blood-2008-02-078071

Conflict of Interest: The authors declare that the research was conducted in the absence of any commercial or financial relationships that could be construed as a potential conflict of interest.

Copyright $\odot 2021 \mathrm{Zhu}$, Chen and Su. This is an open-access article distributed under the terms of the Creative Commons Attribution License (CC BY). The use, distribution or reproduction in other forums is permitted, provided the original author(s) and the copyright owner(s) are credited and that the original publication in this journal is cited, in accordance with accepted academic practice. No use, distribution or reproduction is permitted which does not comply with these terms. 